NASA Technical Memorandum 88933

AIAA-87-0467

\title{
Science and Technology Issues in Spacecraft Fire Safety
}

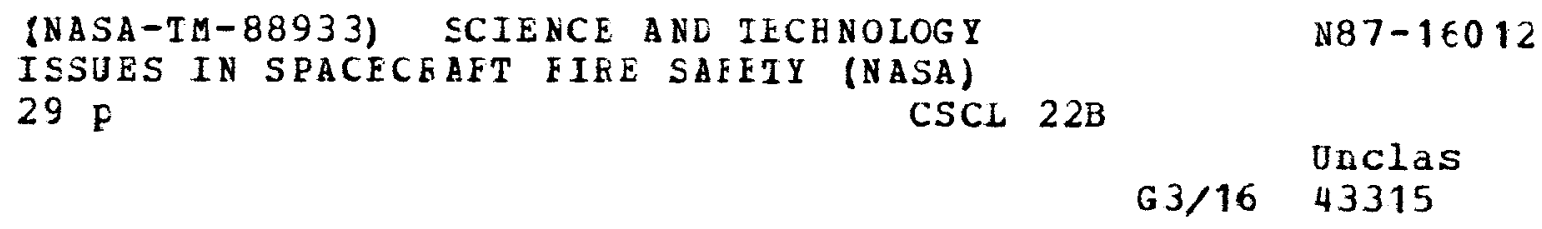

Robert Friedman and Kurt R. Sacksteder Lewis Research Center Cleveland, Ohio

Prepared for the 25th Aerospace Sciences Meeting sponsored by the American Institute of Aeronautics and Astronautics Reno, Nevada, January 12-15, 1987 


\title{
SCIENCE ANO TECHNOLOGY ISSUES IN SPACECRAFT FIRE SAFETY
}

\author{
Robert Friedman* and Kurt R. Sacksteder \\ National Aeronautics and Space Administration \\ Lewis Research Center \\ Cleveland, Ohio 44735
}

\begin{abstract}
The Space Station, a permanently-inhabited orbiting laboratory, places new demands on spacecraft fire safety. Long-duration missions may call for moreconstrained fire controls, but the accessibility of the Space Station to a varlety of users may call for less-restrictive measures. This paper discusses fire safety issues through a review of the state of the art and a presentation of key findings from a recent NASA Lewis Research Center workshop. The subjects covered are the fundamental science of low-gravity combustion and the technology advances in fire detection, extinguishment, materfals assessment, and atmosphere selection. Key concerns are for the adoption of a fire-safe atmosphere and the substitution for the effective but toxic extinguishant, Halon 1301. The fire safety studies and reviews provide several recommendations for further action. One is the expanded research in combustion, sensors, and materials in the low-gravity environment of space. Another is the development of generalized fire-safety standards for spacecraft through cooperative endeavors with aerospace and outside Government and industry sources.
\end{abstract}

\section{INTRODUCTION}

Fire safety has always had a top priority in the planning and operation of human spacefight missions. With designs underway for a permanentlyinhabited orbiting facility, the NASA Space Station, new issues of fire safety must be addressed (refs. 1 and 2). The Space Station will accomnodate a crew of various skills engaged in construction and maintenance, scientific experiments, and commercial technology development. The crew will remain on location for a long time, involving pertods of ordinary living, housekeeping, and recreational activities. The Space Station must serve as a self-contained community, with the hope of rescue many days away. Thus, the Space Station may call for improved and innovative fire safety strategies, as compared to previous space flight programs. On the other hand, it is important to make the Space Station as accessible as possible to a variety of users. Accordingly, fire safety measures must strive for simplicity, flexibility, generalization, and cost effectiveness, without compromising human or structural safety criteria.

A symposium-workshop held at the NASA Lewis on August 20-21, 1986, discussed the needs of future spacecraft fire safety. The published findings of this workshop will not be avallable at the time of presentation of this paper. The purposes of this paper are both to explore the fire safety issues that led

\footnotetext{
*Member AIAA
} 
to the organization of the workshop and to review the preliminary recommendations reached by consensus of the workshop participants.

The organization of this paper covers, first, a general review of the criteria for and the historical approaches to spacecraft fire safety. Then the pertinent scientific and technological issues are presented. Fundamental science involves, foremost, the subject of microgravity combustion. Technology includes applications to fire detection, extinguishment, material assessment, and spacecraft atmosphere selection. Tolerances of human responses to combustion products and inert atmospheres are also reviewed briefly. Finally, the paper discusses application and testing in the space Station.

\section{BACKGROUND OF SPACECRAFT FIRE SAFETY CONCERNS}

\section{Fire Safety Criteria}

Fire, as defined here, is destructive burning. It is the uncontrolled form of combustion, which is a rapid oxidation reaction often useful in energy transfer operations. Safety, of course, is never absolute. What is sought in safety procedures is the minimization of risk, or the potential for harm. While the broad subject of fire risk analysis cannot be covered in this paper, the technical literature contains thorough reviews of fire risk surveys and predictions. Those appearing in the American Soclety for Testing and Materials (ASTM) publications are good examples (refs. 3 and 4 ).

The familiar fire triangle of fuel, ignition, and oxygen (fig. 1) is a simplified description of the ingredients that must be present for fire to occur. The chart lists examples of each of these elements as they apply to spacecraft. Ideally, fire can be prevented if one or more of the fire-triangle elements is removed. This is a fire defense strategy characterized by Raasch, Percy, and Rockoff (r.ef. 5) as DESIGN TO PRECLUDE. This strategy could involve ignition source controls (grounding for example), exclusive use of nonflammable materials, or inert atmospheres (oxygen-deficient atmospheres). For longduration missions in the Space station, one cannot depend on the continuous preclusion of any of the fire elements. For example, ignition sources may occur unpredictably; most materials have some degree of flammability; and, of course, human habitation implies the presence of an oxidizing atmosphere. The second line of fire defense described by Raasch, et al. is DESIGN TO CONTROL. This is the more practical strategy assumed for present-generation spacecraft. The criteria for this defense may be paraphrased as:

(1) An ignition source will always exist, and a fire can start.

(2) A fire must be self limiting within a short distance from its ignition point.

(3) Exposed materials shall be self extinguishing either inherently or in configuration; that is, by limitation of the amount, spacing, or accessibility of the materials.

Point 1, while implying that safe ignition-free practices should be followed, concedes that ignition can occur. Point 2 stresses the concept of 
fire-resistant materials (limited flame spread) rather than absolute nonflammability. Point 3 acknowledges that, if materials are used that are not inherently fire resistant (paper, clothing, for example), they are to be made self-extinguishing or controlled through configuration measures or containment. With respect to the fire triangle, the control strategy is to assume ignition and oxygen but to limit the avallability of fuel. Certain interesting propositions for 1 imiting oxygen are discussed later in this paper.

\section{Historical Approaches to Spacecraft Fire Safety}

Human-crew spacecraft experience. - The first two United States human-crew spacecraft projects, Mercury and Gemini, incorporated fire safety by the use of state-of-the-art nonflammable materials. For reasons of structural 1 imitations and control simplicity, the atmosphere was 100-percent oxygen at $35 \mathrm{kPa}$ ( 5 psia) total pressure. Detection of fires was the responsibility of the astronauts, who had drinking water avallable for extinguishment of incipient fires.

Fire hazards in the early space flights were reviewed thoroughly by Roth (ref. 6). The increased fire risks in the 100-percent oxygen atmosphere were recognized, although Roth felt that safe practices could prevent the possibility of ignitions. The tragic Apollo 204 fire in 1967 occurred during a training session with the atmosphere of 100-percent oxygen at over $110 \mathrm{kPa}$ (1 atm) total pressure. The investigation of the Apollo fire led to many reviews of safe practices, including analytical studies of fire growth by Huggett (ref. 7) and Botteri (ref. 8) and assessments of matertal flammability by Kimzey (ref. 9). For the Apollo project, subsequent launch pad operations used a dual-gas atmosphere, 60 percent oxygen-40 percent nitrogen, which was considered adequate for fire safety at atmospheric pressures (refs. 10 and 11).

The next series of human-crew space flights represented a second generation of more complex vehicles, with larger crews. Skylab, which used Apollo and Saturn vehicle components, was the first United States human-crew space outpost, a primitive forerunner of the NASA Space Station. The Space Transportation System Orbiter (Shuttle) is the present-operation human-crew system, designed for sustained orbital flights of several weeks and accommodating up to eight persons. The normal spacecraft atmospheres are now oxygen-nitrogen mixtures identical to earth sea-level compositions at sea-level pressures. The exception to this is the enriched-oxygen atmosphere required prior to extravehicular activities. No longer are fire detection and extinguishment the sole responsibility of filght crews. The Orbiter has smoke detectors and fixed and portable fire extinguishers for both automatic and manual fire control.

Fire safety standards and reviews. - Criteria for spacecraft material testing and acceptance relative to fire safety were first estabilshed through the NASA Manned Spacecraft Center (now the Lyndon B. Johnson Space Center) (refs. 12 and 13). Testing was formalized into design/development tests and qualification tests. The qualification requirements provided the impetus for the formulation of a new generation of fire-resistance polymers. Early results were presented in a scientific conference, the Conference on Materials for Improved Fire Safety, on May 6-7, 1970 (ref. 14). Two years later, discussion of the advances in spacecraft fire detection and atmospheres were included in the Symposium on Space Simulation (ref. 15). More recentiy, the Conference on 
Fire Resistant Materials of March 1-2, 1979, reviewed the topics of fire-safe materials for aircraft applications, but the papers on combustion toxicology and fire models have results partially applicable to spacecraft (ref. 16).

The present NASA materfals acceptance handbook (ref. 17), NHB 8060.1B, originated in February 1974, and it is now in its second updated version of September 1981. The handbook is again being revised and updated. The purpose of this handbook is to present uniform requirements for materials in habitable areas of spacecraft. Table $I$ is a condensation of the material test requirements in the handbook that are applicable to fire safety. Materials are grouped in two categories, Group I being those that are noncombustible or seifextinguishing on the basis of an upward propagation test, and Group II being all other materials. The handbook defines material selection through nine categories of material usage and 16 test procedures. Group II materials are normally approved only in controlled containment. These materials must be assessed by less-stringent downward propagation, flash, and fire point tests. Al1 the requirements in the NHB $8060.1 B$ are based on a ground-level atmospheric pressure and normal gravity, except for tests at higher pressures on materials for high-pressure oxygen service.

NASA Lewis Research Center fire safety involvement. - NASA Lewis has been associated with many activities related to fire safety, including aircraft crash-fire prevention, low-gravity flammability, and safety analyses by the former Aerospace Safety Research and Data Institute. Studies relevant to spacecraft fire safety were generally conducted on a consulting basis, rather than as continuing, systematic projects. NASA Lewis skills in low-gravity studies and the participation in the Reduced Gravity Combustion Working Group (now the Microgravity Combustion Science Discipline Working Group) attracted outside attention concerned with spacecraft fire safety. In October 1983, the NASA Johnson Space Center asked the Lewis Research Center to investigate two serious fire-related problems:

(1) The fire hazards posed by the spacecraft atmosphere of 40 percent oxygen (now 30 percent) required for the 12- to 24-hr preconditioning in the main cabin prior to an extravehicular activity.

(2) The toxicity of Haion 1301 (a fire extinguishant) and its degradation products.

This request led to a formal review and a workshop at the NASA Johnson Space Center in March 1984. The workshop expanded the fire-related questions to those concerned with low-gravity combustion, fire control, and medical science. The workshop findings were informal and unpublished. However, the recommendations for further inquiry into selected fire-safety topics, impelled by the needs of the developing Space Station program, stimulated the organization of a second workshop. This widely-attended meeting, the NASA Spacecraft Fire Safety Workshop, was held at the NASA Lewts on August 20-21, 1986.

Table II summarizes the contents of this workshop, showing the titles and authors of the presentations. The first portion was a symposium of ten papers that reviewed fundamental knowledge and fire-control standards and their app 11 cations to spacecraft. The second portion of the workshop was five simultaneous discussion forums designed to elicit comments from the participants and recommendations for further study. This paper, to a large extent, covers the findings of the workshop forums. 
Figure 2 shows the relationship of the projected needs for spacecraft fire safety studies. The chart is a necessary, if obvious, lilustration of the steps for such a program. The initial analysis identifies needs, determines acceptable risks, and assesses the extent of present knowledge. This information is applied to guide fundamental and applied research, particularly in combustion, heat transfer, sensors, and material properties. The scientific knowledge can then be used for two purposes: one, the development of applied technology and hardware, as, for example, in fire detection and extinguishment; the other, the compllation of information in data banks and in standards for materials and methods. The workshop recommendations provide an alternative input for systems analysis, defining needs for both fundamental research and technology development. Finally, the goal of the program is towards fire safety in the Space Station and later advanced space systems. It is also important to recognize that the Space Station itself provides a unique test faclitity to verify and perfect technology for future evolutionary versions of the Station.

\section{MICROGRAVITY COMBUSTION SCIENCE}

\section{Introduction}

Basic science relevant to fire safety encompasses many fields, including oxidative reactions, kinetics, heat transfer, mass transfer, radiation, and others. This paper will focus on a review of combustion in low gravity (microgravity), since this process is uniquely associated with the space environment.

\section{Microgravity Analyses}

One is generally aware that "zero gravity" is a misnomer for most space flights. At the usual altitude of a few hundred kilometers for human-crew orbiting spacecraft, the earth gravitational force is nearly the same as that at sea level. The condition of the spacecraft and its contents is that of free fall, experiencing a balance of forces with a very low net acceleration force. Zero acceleration, or zero gravity, is approached only as a limit. There are always some unbalanced drag forces and internal perturbations from the human occupants. Thus the space environment is properly called low gravity or microgravity, terms used here interchangeably.

For over 30 years, 1 imited studies have been conducted under experimental conditions of microgravity. The major application has been toward fluid management for spacecraft propulsion systems. More recentiy, studies have expanded to cover the use of microgravity environments for advancements in material processing and separations. For combustion research, the microgravity environment has also been recognized as a means of eliminating buoyancy forces and the resulting convective flows, thus isolating the effects of other forces, namely pressure, inertia, viscosity, and surface tension. The application of the results of such studies to spacecraft fire safety becomes a useful corollary effort. 
Early studies have modeled the low-gravity flame as a thick sphere, in contrast to the thin, candle-shaped diffusion flame observed under normal gravity (refs. 18 and 19). Other analyses predicted flame length and width from diffusion and momentum balances, for comparison to experimental results (refs. 20 and 21). Most low-gravity combustion research to date relevant to fire safety, however, consists of empirical observations.

\section{Microgravity Experiments}

The microgravity environment is distinguished by the absence of buoyancy forces and natural convection. These conditions may be simulated by several means. A simple technique is to eliminate buoyancy by balancing the densities of the gaseous components. Dosanjh, in a study of smoldering (flameless) combustion of a porous material, regulated the oxidant pressure to minimize gas density differences (ref. 22). Another technique is to increase gravitational acceleration by mounting the experiment on a centrifuge and then to apply dimensional analysis to extrapolate the variable acceleration to microgravity (ref. 23). For fire-safety studies, the most common technique is free fall. Free-fall systems include drop tubes, in which fuel samples fall, and larger drop towers, in which experiment packages fall. Systems of these types, of course, provide only a few seconds of microgravity conditions. For longer lowgravity exposure times of minutes, sounding rockets with data telemetry have been used. A practical compromise in test time against cost is in the use of an airplane flying a Keplerian or ballistic flight path. An airplane test facility provides microgravity exposures up to $30 \mathrm{sec}$ with the advantages of a large volume for experiment packages and the potential for attended testing.

Empirical combustion studies in microgravity have included burning droplets, premixed combustion, diffusion flames, and burning of solids. An early series of tests of significance to spacecraft fire safety were those conducted by $K$ imzey in a KC-135 airplane (ref. 18). These studies provided photographs of flame shapes for plastic samples burning in oxygen and oxygen-enriched air under microgravity. Other pioneering low-gravity combustion tests in airplane facilities were those reported by Colombo, et al., who illustrated the burning of cloth at various atmospheric conditions in microgravity (ref. 24).

Tests conducted in two NASA Lewis drop towers have been the major source of microgravity combustion data important for application to fire safety. The smaller of the two factlities is a tower that provides $2.2 \mathrm{sec}$ of free fall through a drop of $24 \mathrm{~m}$. The experiment package, with its combustion chamber, gas supply, and camera, is contained within a massive box that acts as a drag shield. Three wood spikes extending below the drag shield absorb the deceleration force upon falling into an aerated sand pit. The experiment package floats freely within the drag shield during the drop. A description of the facility and results of first tests were reported by Andracchio and Aydelott (ref. 25). In these tests, the flame spread of ignited cellulose and paper specimens in air and oxygen was investigated (refs. 25 and 26). 0ther pertinent studies in this faclility included tests on diffusion flames of hydrogen and hydrocarbons stabilized on small tubes to correlate normal and low-gravity flame length and radius (refs. 27 to 31 ).

An example of the results of low-gravity combustion studies is illustrated in figure 3. This plot shows measured flame lengths of methane-air diffusion 
flames as a function of time (ref. 31). Combustion was initiated in normal gravity (prior to the drop). At the drop, the flame length first decreased and then gradually increased. During most low-gravity tests, the flame eventually attained a constant length comparable to the mean normal-gravfty flame length. In some cases, however, the flame extinguished prior to achieving a sustained flame length, as also illustrated in figure 3 . The self-extinguished flame, a phenomenon peculiar to microgravity, may be the result of accumulated combustion products impeding the diffusion of oxygen into the flame zone.

A correlation of flame radil for the same test series is shown in figure 4. Normal and low-gravity flame radil are compared on a basis of fuel time, a radius/velocity parameter. The more-spherical low-gravity flame is perhaps 50-percent wider than the corresponding normal-gravity flame. The correlation is derived from a reasonable fit to experimental data, but the relationship does not hold beyond a fuel time of the order of 5 (low fuel velocities).

The larger drop tower facility provides a free fall for $5.2 \mathrm{sec}$ through a drop of $132 \mathrm{~m}$ (refs. 32 and 33 ). The $6.1-\mathrm{m}$ diameter shaft is evacuated to $13 \mathrm{~Pa}$ (100 um of mercury), to eliminate the need for a drop shield around the experiment vehicle. Reported gravitational accelerations in the facility are of the order of $10-5 \mathrm{~g}$. (A " $\mathrm{g}$ " is the unit of normal earth gravity, $9.8 \mathrm{~m} / \mathrm{sec}$.) This is one to three orders of magnitude better than microgravities achieved in other facilities and flights. For fire-related studies, the facility was first used to investigate the flamability of wire bundles in Tefion sleeving in a high-pressure (supercritical) liquid oxygen atmosphere (ref. 33). These tests were prompted by the investigation of the Apollo 13 explosion. Results showed that the insulation burned completely in microgravity; but the flame spread was reduced, compared to reference normal-gravity tests. Later studies investigated the combustion of thin cellulose acetate sheets in supercritical liquid oxygen (ref. 26). Again, flame spread was reduced in microgravity. The ratio of low to normal-gravity flame spread was dependent on the specimen thickness, ranging from 0.6 for the thickest specimen $(0.12 \mathrm{~mm})$ to nearly one for the thinnest $(0.025 \mathrm{~mm})$. Continued studies correlated the low-gravity flame spread based on combustion models and extended it to tests in oxygen and oxygen-inert atmospheres (ref. 34).

The greatest period of research activity in the two NASA Lewis drop towers was between 1968 and 1975 . Recentiy, there has been a resumption in the use of the factilities for combustion studies (ref. 35).

The ideal facility for microgravity research is, of course, an orbiting spacecraft. One important test was the Skylab Experiment M-479 on Zero Gravity Flammability, conducted February 1974 and reported by Kimzey (refs. 1 and 36). In these experiments, specimens of aluminized Mylar, Nylon, polyurethane foam, Teflon, and paper were ignited in a 65-percent-oxygen atmosphere.. The study compared burning rates and the visual appearance of low-gravity flames with corresponding measurements in normal gravity. The extinguishment of flames by venting to the outside vacuum of space was also observed. 


\section{Review of Microgravity Combustion Findings}

Ignition energy for combustion of practical materials is probably unaffected by gravity; however, without natural convection, total incident energy to ignite materials may be reduced. Investigators usually report that low-gravity ignition requirements are the same as those in normal gravity (ref. 36). An exception may be in surface-tension-driven convection in pool fires, a hypothesis based on work in progress. Burning rates of most solid materials appear to be lower under microgravity unless forced-convection flows are present. For diffusion flames, the microgravity flame fronts are more spherical than conventional, normal-gravity flames. The low-gravity flames are more yellow and orange in color than corresponding normal-gravity flames, indicating that they are sootier and cooler. The flames show less "noise" and fluctuations than comparable normal-gravity flames (refs. 25 and 33 ). Selfextinguished flames were observed in microgravity (fig. 3) in some cases, where combustion products may impede oxygen diffusion into the flame zone.

Some combustion analyses propose an estimate of low-gravity flame heights as intermediate between those of normal gravity and inverted gravity (ref. 37). In the diffusion flame experiments discussed by Haggard, however, low-gravity flame lengths may approach those of normal gravity (ref. 31 ).

While these observations imply that the fire hazards may be reduced in microgravity compared to normal gravity, there are other factors that can cancel this apparent safety factor. Spacecraft ventilating systems superimpose forced convection, which may enhance low-gravity flame spread. Haggard investigated diffusion flames in the 2.2-sec drop tower with a diffusion flame tube surrounded by an air annulus (ref. 31). Among the results were the findings that minimum air flows of $10 \mathrm{~cm} / \mathrm{sec}$ could prevent methane flame extinguishment in microgravity.

Certain materials (Kimzey observed this with Nylon) (ref. 36) tend to boil and scatter when burning in low gravity. Globules of hot material, instead of falling to the floor, may drift to ignite adjacent surfaces in low gravity. Work by S. 01 son at NASA Lewis (Technical Memorandum in publication) confirms this hazard in observing the dispersion of particles from Nylon Velcro.

Microgravity flames, while cooler than corresponding normal-gravity flames, may be more radiant due to the concentration of soot particles. This could increase the dangers of flashovers and fire spread to adjacent surfaces through radiant heat transfer.

Finally, flammable sprays, particles, or aerosols may persist in microgravity rather than disperse or settle, imposing a serious ignition threat (ref. 9). Prelliminary analyses of particle cloud combustion have been reported by Berlad and Joshi (ref. 38), but more fundamental and empirical research on these hazards is necessary. 


\section{TECHNOLOGY ISSUES}

\section{Fire Detection}

State of the art. - Incipient fires can be identified by their signatures, or the changes in the environment from a "normal" condition. These signatures may include pressure rise, temperature rise, particle concentration, thermal or visible radiation, chemical species population, and combinations of factors. The fire detector must be positioned for effective transport of the signature information from the affected areas to the detector and must analyze the signature for appropriate action. Rapid activation implies increasing possibilities for "false alarms", which are most undesirable. Furthermore, in the enclosed space of the Space Station, the detection of some noncombustion conditions, such as overheating, smoldering, and catalytic decomposition is also essential.

Fire detection devices thus work on the general principles of heat, smoke, flame, and particle detection. In the confined quarters of the earliest U.S. manned spacecraft, fire sensors were unnecessary, and the astronauts functioned as detectors. Starting with Skylab, the modules were too complex for rellance on human observations. The Skylab detector was a radiometer, sensitfve to ultraviolet at less than $270 \mathrm{~nm}$, responding to $\mathrm{OH}$ radicals generated by a fire (ref. 39). This detector was evaluated in microgravity in a KC-135 airplane, with a combustion target based on the experiment package of Kimzey and Downs (ref. 18). The Shuttle uses nine ionization-type detectors (fig. 5). These are analogous to commercial smoke detectors, operating on the principle that smoke particles impede the mobtlity of atr fons in a chamber, changing the current level to trigger an alarm. For the Shuttle, forced-air fans at each detector provide a flow path to insure the transport of smoke particles to the detector (ref. 40).

Present developments for spacecraft fire sensors include a variety of techniques. DeMeis mentions infrared detectors for flames and coaxial wire detectors for overtemperatures (ref. 1). Recent attention has also been given to a condensation nuclei detector, which counts smoke particles by condensed water droplets around each particle (ref. 41). The application of this method in low gravity is still under evaluation, however.

Workshop recommendations. - The consensus of participants in the NASA Lewis Workshop on Spacecraft Fire Safety is that future fire detection must seek lightweight and rapid means. Rapid identification of location as well as detection is important in the complex, multimodule Space Station. Most effective systems will use localized sensing ports for rapid response. Overheating problems with individual components may be identified by chemical coatings to release indicators, a concept in the early stage of development. The connection of multiple sensors to central annunciator stations through fiber optics appears promising (ref. 42). All of these developments in improved sensors, sensor localization, and centralized detector systems is worthy of further study. Moreover, additional research is warranted on the identification of fire signatures of spacecraft materials in the microgravity environment. 


\section{Fire Extinguishment}

State of the art. - Fires are extinguished through several physical and chemical means. The burning material may be disturbed or removed, the oxidant inerted, the reaction cooled, or the reaction chemically inhibited. Fire extinguishers operate through each or several of these modes. For example, sand buckets disturb the burning material, carbon dioxide blankets the fire excluding oxygen, water cools the reaction, and halogenated hydrocarbons inhibit the combustion reaction.

The Mercury and Gemini spacecraft had water avallable, but they had no systems dedicated solely for fire extinguishing. The Apollo spacecraft had a hand-held fire extinguisher, which contained water and a cellulose gel to form a foam when sprayed (ref. 43). The 100-percent-oxygen atmosphere of the early spacecraft aggravated the flammablility of most materlals, and tests showed that water was the only effective extinguishant (ref. 9). In the more conventional atmospheres of recent spacecraft, halogenated hydrocarbon fire extinguishers are used. For the Shuttle (fig. 5), there are both fixed and portable fire extinguishers. Important features in the Shuttle cabin are ports in the instrument panels to insert the portable fire extinguisher nozzles when necessary to control deep-seated fires.

The use of halogenerated hydrocarbon (Halon) fire extinguishers in the Shuttle is based on favorable experience in the history of the application of these extinguishers to aircraft (ref. 44). A comprehensive review of this class of fire extinguishing agents was the subject of a 1972 symposium (ref. 45). The most widely used compound is Halon 1301 (bromotrifluoromethane, $\mathrm{CF}_{3} \mathrm{Br}$ ), although Halon 1211 (chlorobromodifluoromethane, CF2BrCl) is avallable on some afrcraft, especially in Europe. The principal active specie in Haion 1301 is bromine, which, as an ion, reacts with the $\mathrm{OH}$ radical to stop the combustion chain reaction. Halon 1301 is a most effective extinguishant in volume concentration to 6 percent (refs. 46 and 47). The negative aspect of the use of $\mathrm{Ha}$ ion 1301 is the toxicity and corrosiveness of the halogen acids, $\mathrm{HBr}$ and $\mathrm{HF}$, formed as decomposition products. In open spaces, these products may be easily dispersed, but in a spacecraft, atmospheric contamination after even minor fires is a great concern. The agent itself, when leaked or discharged (it is a gas at normal conditions), can also be toxic (ref. 48).

A recent article (ref. 1) recommends deionized water as an alternative extinguishant for the Space Station. Areas of the Space Station that are uninhabited (electrical cabinets, for example) can be inerted, using nitrogen. The venting of a portion of the spacecraft to fight difficult fires is another interesting measure. Kimzey, in an unpublished memorandum, noted that, in the Space Station, the crew can abandon a module, which then can be depressurized slowly to extinguish the fire. Upon repressurization, the atmosphere could then be sampled for residual combustion and extinguishant products before reboarding.

Workshop recommendations. - The consensus of participants in the NASA Workshop on Spacecraft Fire Safety is that increased efforts should be made in the technology development of systems, such as defonized water, which, while innovative in application, are proven in concept. Again, further studies of the pecularities of flame propagation and extinguishment in low gravity are highly recommended. Recent work by Ronney (ref. 35) in the NASA Lewis 2.2-sec 
drop tower studied the change in lean flammability limits of diffusion flames doped with small quantities of Halon 1301. Potential improvements in extinguishment in spacecraft would also benefit from reviews of analogous techniques, based on experience with aircraft and submarines (ref. 49).

\section{Materials Assessment}

State of the art. - One expects that, from the start, materials for inclusion on human-crew spacecraft would be strictly controlled. The 100-percent-oxygen atmosphere of the early spacecraft created a hazardous situation in which few materials, even metals, are truly nonflammable. The stringent materials requirements acted as a catalyst for the creative invention and development of "space age" materials. The 1971 Conference on Materials for Improved Fire Safety (ref. 14) was a forum for the review of the progress at that time in nonmetalilc structural materials, foams, and insulations, as well. as in the new flammability testing and acceptance procedures. Materials screening involves the verification of the acceptability of the bulk material followed by qualification testing in specific configurations. Flammability tests adapted for spacecraft, as described in the early reviews (refs. 13 and 43), Included conventional flash point tests as well as unique upward propagation, downward propagation, drip ignition, short-circuit ignition, and autoignition tests.

Current spacecraft have less hazardous sea-level air atmospheres, but fire safety measures through materials control are still imperative. At present, NASA imposes the flammabilty and off-gassing requirements of the NHB $8060.1 B$ handbook (ref. 17) in addition to other documented specifications on strength, corrosion resistance, and vacuum permeability.. Material control procedures are through computerized tracking systems, with review of approvals and waivers.

The long-duration habitation and the wide range of living and working activities in the Space Station will expand the range of materials on board. Not only must inventoried materials be considered, but also extraneous items or contraband. Papers, books, films, recreationà items, nonissue clothing items, and souvenirs will be brought on board. Secured, fire-resistant storage areas for personal items may be the only practical approach. Again, an analogy may be pursued in terms of similar problems with flammable items, trash, and waste in airplane cabins (ref. 50).

The aim of present day flammablitty testing is to provide useful measurements that can be interpreted on the basis of the underlying chemical and physical principles. Material tests, of necessity, are usually on small-scale samples. The tests serve to predict full-scale behavior to guide the ultimate quality assurance using, as far as possible, standardized methods and procedures. Hilado has assessed various fire response test methods for suitability in screening aerospace materials (ref. 51). One recommended method, shown in figure 8 , tests the behavior of a 150 by $150 \mathrm{~mm}$ specimen under variable thermal exposures. This method, called the OSU calorimeter, is now standardized as ASTM E906-83 (ref. 52). The advantage of the use of standardized industry methods for fire safety is the opportunity to generalize techniques with precision limits determined from interlaboratory cooperative testing. For the Space Station, expansion of the NASA methods of NHB 8060.1B to include the generalized procedures witl assist users by allowing more simplified and convenient screening of research and housekeeping materials. 
Workshop recommendations: - The consensus of participants in the NASA Fire Safety Workshop is that advancements and updating of materlal testing methods and standards are necessary. The long-duration operation of the Space Station demands attention to time-related testing, to allow for deterioration and aging of materials, for example. The unique low-gravity environment, as already discussed, makes specialized testing necessary, including methods appropriate to determine spontaneous ignition and low-temperature combustion (smoldering). The latter phenomenon is apt to occur particularly with the many foamed materials used today.

\section{Spacecraft Atmospheres}

State of the art. - Simplicity of controls and the confidence of ground experience would seem to favor the retention of a sea-level oxygen-nitrogen atmosphere in spacecraft. Nevertheless, research has shown that alternative atmospheres can have advantages for fire safety. The practicality of these atmospheric systems for introduction into the Space Station is still unknown, but the concepts are worthy of further study and development.

An atmosphere that inhibits combustion may, on the contrary, support human 11fe. Sea-level air contains 21 mole (volume) percent oxygen, corresponding to a standard partial pressure of $21.2 \mathrm{kPa}$. Table III shows standard atmospheric values at several altitudes (ref. 53). On the ground, humans can acclimate in permanent settlements at altitudes at least as high as $2400 \mathrm{~m}$ $(8000 \mathrm{ft})$. Thus, human activities are feasible over a range of atmospheric pressures from below 74 to 100 percent of sea level, corresponding to oxygen partlal pressures of 16 to $21 \mathrm{kPa}$. The amount of nitrogen or, within limits, the total pressure of the atmosphere is immaterial for human sustenance. For combustion, on the other hand, an atmosphere is required with a minimum concentration, or mole percent, of oxygen. The presence of nitrogen affects combustion because combustion energy is used to heat the inert atmosphere, cooling and possibly quenching the flame. In fact, the sensitivity of combustion to the oxygen fraction of the atmosphere is the basis for the oxygen index test, a method to determine the flammability of materials through the minimum percent oxygen necessary to sustain combustion (generalized as ASTM 02863-77) (refs. 54 and 55 ).

As a consequence to these differences in atmospheric effects, it is evident that atmospheres with partial pressures acceptable for humans, but with reduced mole fractions of oxygen, can reduce fire hazards in spacecraft. This use of modified spacecraft atmosphere had been proposed about 20 years ago based on simple flame-spread tests (ref. 56). A further application of this principle is in nitrogen flooding as a fire fighting measure, already suggested for submarines by Carhart (ref. 49). In this procedure, nitrogen is used to increase the total pressure to suppress fires by lowering oxygen concentration. This atmosphere retains the original oxygen partial pressure.

An alternative to reduced-oxygen atmospheres for fire safety is one with other than nitrogen as the inert constituent. Helium, which is used, for example, as the diluent in diving atmospheres, appears to inhibit ignition (ref. 57). Once fires occur, however, helium, which has a low specific heat per mole, promotes fire spread. In fact, of the common elemental gases, nitrogen has the most favorable inhibition properties. Studies by McHale (ref. 58) 
and Huggett (ref. 59) have proposed the substitution of fluorinated hydrocarbons, such as carbon tetrafluoride, $\mathrm{CF}_{4}$, which have high molar specific heats, for at least part of the nitrogen in a fire-safe atmosphere. The fluorinated hydrocarbons not only suppress flame spread by their high specific heat, but can produce reaction-inhibiting spectes analogous to the action of Halon 1301 extinguishant. These halogenated gases appear to be physiologically inert, but confidence in their usage must be demonstrated by long-term testing.

Workshop recommendations. - The participants in the NASA Spacecraft Fire Safety Workshop proposed three alternative spacecraft atmospheres, judged to be fire safe, for scientific investigation and technology development. These atmospheres, in the priority given, are:

(1) $150 \mathrm{kPa}$ total pressure $(1.5 \mathrm{~atm}), 12 \mathrm{~mole}$ percent oxygen;

(2) $100 \mathrm{kPa}$ total pressure $(1.0 \mathrm{~atm})$, and minimum oxygen concentration;

(3) Atmospheres with diluents other than nitrogen.

The first recommendation is an atmosphere that retains the sea-level partial pressure of oxygen. The mole percent of oxygen, however, is low enough that fire hazards should be greatly reduced. Unfortunately, the higher total pressure may call for more complex and heavier spacecraft structures. The second recommendation avoids this total-pressure difficulty. A minimum oxygen mole fraction of 16 percent would correspond to standard earth conditions at $2200 \mathrm{~m}(7200 \mathrm{ft})$ altitude (Table III). This reduced partlal pressure of oxygen for the Space Station is one of the options presented in a paper by Grieder (ref. 60). The third recommendation is a consequence of studies such as those of McHale (ref. 58) and Huggett (ref. 59). These substitute atmospheres present the most innovative approach, but they are probably the least feasible.

\section{HUMAN FACTORS}

\section{Combustion Product Toxicity}

It is well established that the principal danger to humans in fires is the toxic and asphyxiating combustion products, more than the heat of combustion (ref. 61). Carbon monoxide is the principal toxic compound found in smoke, although burning wood and plastics can generate hydrogen cyanide, hydrogen chloride, acrolein, and other toxic gases. Carbon dioxide is relatively nontoxic, but its presence in smoke can exclude oxygen, and it may have synergistic effects in increasing carbon monoxide toxicity (ref. 62). Particulates in smoke also contribute to reduced visibility, a danger in impeding escape.

Chemical and biological techniques exist for the assessment of the flammability hazards of present spacecraft materials (refs. 51 and 63). The evolution and dispersion of toxic products of combustion, however, depend on many physical factors in the spacecraft installation. The low-gravity environment may contribute to toxic-gas generation. Diffusion-flame observations show that low-gravity combustion is often incomplete, with equilibrium products favoring carbon monoxide. Cleanup and removal of the toxic products in spacecraft may be difficult, and contaminants are often detectible with great precision. Hence, zero exposure cannot be expected, and permissible long-duration limits must be established for practicality. Existing standards are often based on old tests and statistical analyses and should be updated. 
As noted in a previous section, the extinguishment of fires can add contaminants to the spacecraft atmosphere. Specifically, Halon 1301, while the acceptable current extinguishant, is known to generate halogen acids when heated. For spacecraft, there has been no actual experfence in the aftermath of extinguisher use, and the authors are not aware of any occasion when extinguishers have been discharged in orbiting spacecraft. In the future, however, there is likelihood that in the long life of the Space Station, minor or incipient fires will require attention to the use of extinguishers and clean up of residues.

\section{Submarine and Aircraft Experience}

Physical and blological stresses and hazards in a spacecraft are simflar: in many respects to those present in submarines and aircraft. The closed environment in the submarine provides a useful model for atmospheric control and contaminant removal (ref. 64). Modern submarines have provisions for oxygen makeup from water hydrolysis, venting the hydrogen (ref. 49). They also have elaborate scrubbing, absorption, and precipitation equipment to remove atmospheric contaminants, including toxic and flammable gases. On the other hand, the environment in the submarine is normal gravity and the external pressure is high, causing inward leakage if the shell is damaged. Spacecraft contaminant removal is more difficult, if for no other reason than operations are under microgravity.

The Special Aviation Fire and Explosion Reduction (SAFER) Advisory Committee Report includes a number of recommendations that certainly apply to spacecraft as well as to aircraft (ref. 65). In brief, pertinent sections of the report refer to toxic and smoke hazards, chemical product detection, animal testing, toxicity standards, and material ratings.

\section{Recommendations}

The NASA Spacecraft Fire Safety Workshop included a discussion forum on human responses to combustion products and inert atmospheres. The participants urged continued study on combustion and extinguishment in microgravity for prediction of toxic-product generation. While microgravity may not influence the equilibrium chemical reactions of combustion and pyrolysis, it can affect that mass and energy transfer into the atmosphere. Acceptance of many materials can be based on the potential generation of toxic combustion products, as well as on flammabllity. Further biological testing is certainly necessary to determine acceptable exposure levels for the long-duration exposure expected in the Space Station. Present data are often marginally adequate and usually based on extrapolation of limited animal tests.

The Space Station crew will be composed of persons of differing experience and skills. Although adequate fire-control instructions will be part of the advance training for the crew, the workshop participants recommended spectalized training for at least one crew member on duty. This designated fire marshall will be responsible for the enforcement of fire safety regulations and for the direction of fire fighting and evacuation, if ever necessary. 


\section{APPLICATION TO THE SPACE STATION}

\section{Initial Operating Condition}

Because of the long lead time for design, development, fabrication, and testing, safety philosophies and most procedures have already been determined for the initial configuration of the Space Station. The Initial operating Condition has establistied requirements based on the experience of past space missions. Certain of the ground rules for fire safety are paraphrased here, selected from items in the comprehensive list of crew safety criteria published by Percy, et a1. (ref. 66).

(1) No credible combination of two errors or fallures shall result in the potential for crew injury or loss of the Space Station.

(2) No credible single error or fallure shall result in damage to the Space Station. isolated.

(3) The Space Station shall be designed so that any damaged module can be

(4) Any volume shall be capable of sustaining the whole crew, providing a safe haven.

(5) Atmospheric stores capabllity shall be sufficient for two full repressurizations of each habitable module. performed.

(6) Real time monitoring of the atmosphere constituents shall be

(7) Provision shall be made for the detection, handling, and containment of toxic and flammable materials.

(8) Primary structural materials shall be nonflammable.

(9) Normally-exposed nonmetallic materials shall be self-extinguishing in the most severe oxidizing environment, and means shall be provided for fireproof storage of nonself-extinguishing materials when they are not in use.

(10) All personal items shall be screened for flammability and toxicity.

The strict criteria inherent in the Initial Operating Condition do not imply that there is no opportunity for inclusion of advanced fire-safety controls in the initial space Station. An important guideline for the Space Station is in the accommodation of science and industrial operations. The Space Station is to serve its users, not its designers (ref. 67). Hence, established fire-control procedures are open to modification if the changes can promote the usefulness and application of the missions, without compromising the safety criteria.

The atmosphere in the Space Station habitation modules merits comment. Until feasibility of an alternative fire-safe atmosphere is demonstrated, the obvious atmosphere in the Space Station must be sea-level air, 21-mole-percent oxygen. For extravehicular activities, the mobility of space suit hand joints 
1 imits the total pressure in the suit to about $30 \mathrm{kPa}$ ( $4.3 \mathrm{ps} 1 \mathrm{a})$, maintained by a 100-percent-oxygen atmosphere. In order to precondition the astronauts to avoid nitrogen bubbles in the body tissues caused by the sudden pressure change, the module atmosphere is reduced to $70 \mathrm{kPa}$ for 12 to $24 \mathrm{hr}$ prior to the activity. This creates a temporary enriched atmosphere of 30 percent oxygen. A hard suit operating at $55 \mathrm{kPa}(8 \mathrm{psia})$ total pressure, which is a low enough pressure differential to eliminate the need for preconditioning, is presentiy under study (ref. 68).

\section{Space Station as a Test Facility}

Without a doubt, there will be growth versions of the Space Station beyond the Initial Operating Condition. Accordingly, the Space Station itself, or free-flying platforms assoctated with the Space Station, offers potential as a test facllity. For furthering the prevention, detection, and control of fires, many studies can use the Space Station to advantage. The long-term microgravity environment allows research and development on basic combustion, atmospheres, sensors, materials, and other concerns. Detached volumes can also provide for large-scale research to validate scaling theories.

The access of a wide variety of users to the Space Station will be aided by the adoption of generalized fire standards. Standards are based on a consensus of design and evaluation. Again, the Space Station can be employed as a. test facility for interlaboratory comparisons to determine precision and blas. There is already a trend toward the formulation of aerospace fire safety standards. As examples, ASTM standards F501-84 "Test Method for Aerospace Materials Response, with Vertical Test Specimens", and F777-82, "Test Method for Resistance of Electrical Wire Insulation Materials to Flame at $60^{\circ}$ ", (ref. 69) are definitive and standardized versions of comparable methods in the NHB 8060.1B handbook (ref., 17).

\section{CONCLUDING REMARKS}

Current fire safety criteria are adequate and effective for present spacecraft. For the Space Station, a permanently-inhabited orbiting laboratory, the long-duration missions may call for improved and innovative fire-control techniques. Conversely, the proposed accessibility of the Space Station to a variety of users may call for less restrictive and less costly measures. This paper discusses fire safety issues through a review of the state of the art and a presentation of key findings from a recent NASA Lewis workshop. The issues of interest to fire safety include the science of microgravity combustion; the applications to fire detection, extinguishment, materials assessment, and spacecraft atmosphere selection; and the implications for human responses to atmospheres and contaminants.

Two fire-safety questions that stimulated the expansion of fire safety inquirtes toward Space Station application still remain to be resolved. These are, in brief:

(1) How to reduce the hazards of the oxygen-enriched atmosphere prior to extravehicular activities, and 
(2) How to reduce the toxic hazard of the current and most effective extinguishant, Halon 1301 .

The results of this review point to the necessity for continued research in combustion fundamentals under microgravity and continued technology development into fire detection, fire control, innovative materials and testing, and alternative fire-safe atmospheres. A greater reliance on generalized standards would be most valuable. This would be alded by the review of existing studies and the cooperation with government and industrial sources of fire-safety knowledge.

\section{REFERENCES}

1. Deleis, R.: Safety in the Space Station. Aerospace America, Vol..24, No. 5, May 1986, pp. 26-29.

2. Peercy, R.L., Jr.; Raasch, R.F.; and Rockoff, L.A.: Space Station Crew Safety Alternatives Study-Final Report. Vol. I - Final Summary Report. NASA CR 3854, June 1985.

3. Roux, H.J.: A Discussion of Fire Risk Assessment in Castino, G.T.; and Harmathy, T.Z.; eds.: Fire Risk Assessment. ASTM STP 762, Amer. SOC. for Testing and Materials, Phlladelphta, 1980, pp. 16-27.

4. Ne1son, G.L.: Perspective on Transportation-A Delphi Study. ASTM Standardization News, Vo1. 13, No. 12, December 1985, pp. 50-55.

5. Raasch, R.F.; Peercy, R.L., Jr.; and Rockoff, L.A.: Space Station Crew Safety Alternatives Study-Final Report. Vol. II - Threat Development. NASA CR 3855, June 1985.

6. Roth, E.M.: Space Cabin Atmospheres. Part II - Fire and Blast Hazards. NASA SP-48, 1964.

7. Huggett, C.; Spurlock, J.M.; von Elbe, G.; Tobriner, M.W.; Gtft, R.; and Grossman, J.R.: Analytical Study of the Flammability of Spacecraft Materials. Atlantic Research Corp. (NASA Contract NAS9-6854), Final Report, Apri1 1967.

8. Botter1, B.P.: Fire Protection for Oxygen Enriched Atmosphere Applications, in Proceedings of Fire Hazards and Extinguishment Conference. Air Force AMO TR 67-2, 1967, PD. 39-69.

9. Kimzey, J.H.: Flammability and Toxic Materials in the Oxygen Atmosphere of Manned Spacecraft. NASA TN D-3415, May 1968.

10. Johnston, R.S.: Combustion Safety in the Spacecraft Environment. Aerospace Medicine, Vo1. 40, 1969, pp. 1197-1202.

11. Bricker, R.W.; Crabb, J.P.; and Spiker, I.K.:. Flammability Tests for Apollo Command Module and Lunar Module Mockup, in Bolger, P.H.; ed.: Conference on Materials for Improved Fire Safety. NASA SP-5096, 1971, pp. 43-54. 
12. Johnston, R.L.; and Pippen, D.L.: Development of Materials Screening Tests.for Oxygen-Enriched Environments, in Bolger, P.H.; ed.: Conference on Materials for Improved Fire Safety. NASA SP-5096, 1971, pp. 23-27.

13. Sauers, D.G.: Special Flammab17ity Test Techniques, in Bolger, P.H.; ed.: Conference on Materials for Improved Fire Safety. NASA SP-5096, 1971, pp. 179-185.

14. Bolger, P.H.; ed.: Conference on Materials for Improved Fire Safety. NASA SP-5096, 1971.

15. Anon.: Space Simulation. NASA SP-298, 1972.

16. Kourtides, D.A.; and Johnson, G.A.; eds.: Conference on Fire Resistant Materials. NASA CP 2094, July 1979.

17. NASA Office of Space Transportation Systems: Flammability, Odor, and Offgassing Requirements and Test Procedures in Environments that Support Combustion. NASA NHB 8060.1B, September 1981.

18. Kimzey, J.H.; Downs, W.R.; Eldred, C.H.; and Norris, C.W.: Flammability in Zero-Gravity Environment. NASA TR R-246, October 1966.

19. Downs, W.R.: The Combustion Process, in Bolger, P.H.; ed.: Conference on Materials for Improved Fire Safety. NASA SP-5096, 1971, pp. 3-7.

20. Edelman, R.B.; Fortune, O.F.; Weflerstein, G.; Cochran, T.H.; and Haggard, J.B., Jr.: An Analytical and Experimental Investigation of Gravity Effects on Laminar Gas Jet-Diffusion Flames. Fourteenth Symposium (Internationa1) on Combustion. The Combustion Institute, Pittsburgh, 1973, pp. 399-412.

21. Haggard, J.B., Jr.; and Cochran, T.H.: Stable Hydrocarbon Diffusion Flames in a Weightiess Environment. Comb. Sci. and Technol., Vol. 5, 1972, pp. 291-298.

22. Dosanjh, S.; Peterson, J.; Fernandez-Pello, A.C.; and Pagni, P.J.: Buoyancy Effects on Smoldering Combustion. Paper 85-289 presented at the 36th Internat. Astronaut. Conf., October 1985.

23. Altenkirch, R.A.; Eichhorn, R.; and Shang, P.C.: Buoyancy Effects on Flames Spreading Down Thermally Thin Flames. Comb. and Flame, Vol. 37 , 1980, pp. 71-83.

24. Colombo, G.V.; Mader, P.P.; Neustein, R.A.; and Richardson, D.E.: The Effect of Atmosphere Selection and Gravity on Burning Rate and Ignition Temperature. McDonne11 Douglas DAC-62431, NASA CR-106652, October 1968.

25. Andracchio, C.R.; and Aydelott, J.C.: Comparison of Flame Spreading Over Thin Flat Surfaces in Normal Gravity and Weightlessness in an Dxygen Environment. NASA TM X-1992, May 1970.

26. Andracchio, C.R.; and Cochran, T.H.: Burning of Solids in Oxygen-Rich Environments in Normal and Reduced Gravity. NASA TM X-3055, May 1974. 
27. Cochran, T.H.; and Masica, W.J.: Effects of Gravity on Laminar Gas Jet Diffusion Flames. NASA TN D-5872, June 1970.

28. Cochran, T.H.; and Masica, W.J.: An Investigation of Gravity Effects on Laminar Gas-Jet Diffusion Flames. Thirteenth Symposium (International) on Combustion, The Combustion Institute, Pittsburgh, 1971, pp. 821-829.

29. Cochran, T.H.: Experimental Investigation of Laminar Gas Jet Diffusion Flames in Zero Gravity. NASA TN D-6523, January 1972.

30. Haggard, J.B.,.Jr.; and Cochran, T.H.: Hydrogen and Hydrocarbon Diffusion Flames in a Weightiess Environment. NASA TN D-7165, Feburary 1973.

31. Haggard, J.B., Jr.: Forced and Natural Convection in Laminar-Jet Diffusion Flames. NASA TP T841, June 1981.

32. Petrash, D.A.; and Corpas, E.L.: Zero Gravity Facility for Space Vehicle Fluid Systems Research, in Realism in Environmental Testing and Control. Proc. of the 19th Annual Meeting, Inst. Environmental Sciences, 1973, pp. 480 -482.

33. Cochran, T.H.; Petrash, D.A.; Andracchio, C.R.; and Sotos, R.G.: Burning of Tefion-Insulated Wires in.Supercritical Oxygen at Normal and Zero Gravity. NASA TM X-2174, Feburary 1971.

34. Andracchto, C.R.; and Cochran, T.H.: Gravity Effects on Flame Spreading Over Solid Surfaces. NASA TN D-8228, May 1976.

35. Ronney, P.D.: Effect of Gravity on Halocarbon Flame Retardant Effectiveness. Acta Astronautica, Vol. 12, 1985, pp. 915-921.

36. Kimzey, J. H.: M479 Zero Gravity Flammability, in Proc. Third Space Processing Symposium - Skylab Results. Vol. I, NASA TM X-70252, June 1974, pp. $115-130$.

37. Lavid, M.; and Berlad, A.L.: Gravitational Effects on Chemically Reacting Laminar Boundary Layer Flows Over a Horizontal Flat Plate. Sixteenth Symposium (Internationa 1) on Combustion. The Combustion Institute, Pittsburgh, 1977, pp. 1557-1568.

38. Berlad, A.L.; and Joshi, N.D.: Gravitational Effects on Stabilized Premixed, Lycopodium-Air Flames. Comb. Scl. and Technol., Vol. 47, 1985, pp. 56-59.

39. Linford, R.M.F.: Experiments with the Skylab Fire Detectors in Zero Gravity, in Space Simulation. NASA SP-298, 1972, pp. 42-55.

40. Kubicki, D.J.: Fire Protection and Rescue Planning for the NASA Space Station. Fire Journal, Vol. 75, No. 4, July 1981, pp. 34-40, 127.

41. Bricker, R.W.: Test Results from Comparative Evaluation of a Condensation Nuclet fire Detector. NASA CR 3874, 1985. 
42. McGonigle, R.D.; Jackson, H.W.; and Beavers, R.R.: Applicability of Fiber Optics to Aircraft Fire Detection Systems. AFAPL TR-78-84, October 1978.

43. Anon.: Systematic Control of Nonmetalilc Materials for Improved Fire Safety. NASA SP-5109, 1972.

44. Botteri, B.P.: Aircraft fire Protection Technology, in Aircraft Fire Safety. AGARD CP-166, October 1975, pp. 18-1 to 18-15.

45. Christian, W.J.; and Wands, R.C.; eds.: Symposium on an Appraisal of Halogenated Fire Extinguishing Agents. National Academy of Sciences, Washington, 1972 .

46. Gassmann, J.J.; and Marcy, J.F.: Application of Halon 1301 to Aircraft Cabin and Cargo Fires, in Christian, W.J.; and Wands, R.C.; eds.: Symposium on an Appraisal of Halogenated Fire Extinguishing Agents, National Academy of Sciences, Washington, 1972, pp. 173-187.

47. Reichelt, E.F.; Walker, J.; Vickers, R.N.; and Kwan, A.J.: Report of Testing Results: Halon 1301 vs. Water Sprinkler Fire Protection for Essential Electrical Equipment. AFESL-TR-82-28, July 1982.

48. Reinhardt, C.F.; and Reinke, R.E.: Toxicology of Halogenated Fire Extinguishing Agents Halon 1301 (Bromotrifluoromethane), in Christian, W.J.; and Wands, R.C.; eds.: Symposium on an Appraisal of Halogenated Fire Extinguishing Agents, National Academy of Sciences, Washington, 1972, pp. 67-78.

49. Carhart, H.W.; and Fielding, G.H.: Applications of Gaseous Extinguishants in Submarines, in Christian, W.J.; and Wands, R.C.; eds.: Symposium on an Appraisal of Halogenated Fire Extinguishing Agents, National Academy of Sciences, Washington, 1972, pp. 67-78.

50. Fewe 11, L.A.: Fire Resistant Aircraft Seat Program, in Kourtides, D.A.; and Johnson, G.A.; eds.: Conference on Fire Resistant Materials. NASA CP 2094, July 1979, pp. 135-166.

51. Hilado, C.A.: Fire Response Test Methods for Aerospace Materials. Jour. Fire and Flammability, Vol. 9, 1978, pp. 217-228.

52. Bullding Seals and Sealants; Fire Standards; Building Construction. Annual Book of ASTM Standards, Vol. 04.07, Amer. Soc. for Testing and Materials, Philadelphia, 1986.

53. Dubin, M.; Hull, A.R.; and Champion, K.S.W.: U.S. Standard Atmosphere, 1976. NOAA-S/T 76-1562, October 1976.

54. Ikeda, G.K.: Oxygen Index Tests to Evaluate the Sultability of a Given Material for Oxygen Service, in Werley, B.L.; ed.: Flammability and Sensitivity of Materials in 0xygen-Enriched Atmospheres. ASTM STP 812 , Amer. Soc. for Testing and Materials, Philadelphia, 1983, pp. 56-67. 
55. Plastics (II). Annual Book of ASTM Standards, Vo1. 08.02, Amer. Soc. for Testing and Materials, Philadelphia, 1986.

56. McAlevey, R.F., III; and Magee, R.S.: A Criterton for Space Capsule Fire Hazard Minimization. Jour. Spacecraft and Rockets, Vol. 4, 1967, p. 1390.

57. Bonura, M.S.; Nelson, W.6.; et al.: Engineering Criteria for Spacecraft Cabin Atmosphere Selection. NASA CR-891, September 1967.

58. McHale, E.T.: Habitable Atmospheres Which Do Not Support Combustion, in Space Simulation. NASA SP-298, 1972, pp. 331-335.

59. Huggett, C.: Habitable Atmospheres Which Do Not Support Combustion. Comb. and Flame, Vol. 20, 1973, pp. 140-142.

60. Grleder, H.R.: Atmospheric Composition, in Mason, J.A.; and Johnson, P.C., Jr.; eds.: Space Station Medical Sciences Concepts. NASA-TM 58255, February 1984, pp. 38-41.

61. Clarke, F.B., III: Toxicity of Combustion Products: Current Knowledge. Fire Jour., Vol. 77, No. 5, September 1983, Pp. 84-101, 108.

62. Babrauskas, V.; Levin, B.C.; and Gann, R.G.: A New Approach to Fire Toxicity Data for Hazard Evaluation. ASTM Standardization News, Vol. 14, No. 9, September 1986, pp. 28-33.

63. Russo, D.M.: Recent Advances in Materials Toxicology, in Kourtides, D.A.; and Johnson, G.A.; eds.: Conference on Fire Resistant Materials. NASA CP 2094, July 1979, pp. 27-43.

64. Solitario, W.A.; Blalecki, A.; and Laubach, G.E.: An Approach to Trace Contaminant Control for a Spacecraft Atmosphere, in Chemical Engineering Techniques in Aerospace. Chem. Eng. Progress Symp. Series, Vol. 60 , 1964, pp. 188-198.

65. Enders, J.H.; and Wood, E.C.: Final Report of the Special Aviation Fire and Explosion Reduction (SAFER) Advisory Committee, Vol. I. FAA ASF-80-4, June 1980.

66. Peercy, R.L., Jr.; Raasch, R.F.; and Rockoff, L.A.: Space Station Crew Safety Alternatives Study-Final Report. Vol. IV-Appendices. NASA CR 3837, June 1985.

67. Fletcher, J.C.: Space Station 1986-Now More Than Ever. Aerospace America, Vol. 24, No. 9, September 1986, pp. 23-27.

68. Carlisle, R.; and Nolan, M.: Space Station 1986-Frontier of Technology. Aerospace America, Vol. 24, No. 9, September 1986, pp. 48-53.

69. Space Simulation: Aerospace Materlals; High Modules Fibers and Components. Annual Book of ASTM Standards, Vol. 15.03, Amer. Soc. for Testing and Materials, Philadelphia, 1986. 
TABLE I. - EXAMPLES OF MATERIAL TEST REQUIREMENTS IN NASA HANDBOOK

\begin{tabular}{|c|c|c|}
\hline \multirow[t]{2}{*}{ Test type } & \multicolumn{2}{|c|}{ Applicable material requirementsa } \\
\hline & Group I & Group II \\
\hline Upward propagation & $A 11 \mathrm{~B}$ & (b) \\
\hline Downward propagation & Not required & $\begin{array}{l}\text { Materials for sealed } \\
\text { or vented containers } \\
\text { or where approved. }\end{array}$ \\
\hline Flash point & Not required & $\begin{array}{l}\text { Materials for sealed } \\
\text { or vented containers } \\
\text { or where approved. }\end{array}$ \\
\hline Fire point & Not required & $\begin{array}{l}\text { Materials for sealed } \\
\text { or vented containers } \\
\text { or where approved. }\end{array}$ \\
\hline $\begin{array}{l}\text { Electrical wire } \\
\text { insulation and } \\
\text { accessory flammability }\end{array}$ & $\begin{array}{l}\text { Electrical } \\
\text { components }\end{array}$ & Not approved \\
\hline $\begin{array}{l}\text { Gaseous oxygen - } \\
\text { mechanical impact }\end{array}$ & $\begin{array}{l}\text { Oxygen service, } \\
\text { as applicable }\end{array}$ & Not approved \\
\hline $\begin{array}{l}\text { Gasous oxygen - } \\
\text { pneumatic impact }\end{array}$ & $\begin{array}{l}\text { Oxygen service, } \\
\text { as applicable }\end{array}$ & Not approved \\
\hline
\end{tabular}

achart is simplified. Consult Handbook for actual applications. 17

bGroup I materials pass upward propagation test. Group II do not. 
TABLE II. - AGENDA FOR NASA SPACECRAFT FIRE SAFETY WORKSHOP

AUGUST 20 - 21, 1986

\begin{tabular}{|c|c|c|}
\hline Paper topic & Author & Affiliation \\
\hline $\begin{array}{l}\text { Techniques for fire } \\
\text { detection }\end{array}$ & R. Bukowski & $\begin{array}{l}\text { NBS Center for } \\
\text { Fire Safety }\end{array}$ \\
\hline $\begin{array}{l}\text { Fire related standards } \\
\text { and testing }\end{array}$ & V. Babrauskas & $\begin{array}{l}\text { NBS Center for } \\
\text { Fire Safety }\end{array}$ \\
\hline $\begin{array}{l}\text { Fire extinguishment and } \\
\text { inhibitaion }\end{array}$ & J. de Ris & $\begin{array}{l}\text { Factory Mutual } \\
\text { Research Corp. }\end{array}$ \\
\hline Inerting and atmospheres & H. Carhart & $\begin{array}{l}\text { Naval Research } \\
\text { Lab. }\end{array}$ \\
\hline $\begin{array}{l}\text { Fire-related medical } \\
\text { science }\end{array}$ & D. Knight & $\begin{array}{l}\text { Naval Submarine } \\
\text { Medical Lab. }\end{array}$ \\
\hline $\begin{array}{l}\text { Aircraft fire safety } \\
\text { research }\end{array}$ & B. Botterf & $\begin{array}{l}\text { AF Wright Aero. } \\
\text { Labs. }\end{array}$ \\
\hline $\begin{array}{l}\text { Space station environments } \\
\text { and safety }\end{array}$ & M. Cole & $\begin{array}{l}\text { NASA Johnson } \\
\text { Space Center }\end{array}$ \\
\hline $\begin{array}{l}\text { Microgravity combustion } \\
\text { fundamentals }\end{array}$ & K. Sacksteder & $\begin{array}{l}\text { NASA Lewts } \\
\text { Research Ctr. }\end{array}$ \\
\hline $\begin{array}{l}\text { Spacecraft material } \\
\text { flammability testing }\end{array}$ & P. LeDoux & $\begin{array}{l}\text { McDonnell } \\
\text { Douglas-Houston }\end{array}$ \\
\hline $\begin{array}{l}\text { Ignition and combustion } \\
\text { of metals }\end{array}$ & $\begin{array}{l}\text { F. Benz and } \\
\text { S. Zhu }\end{array}$ & $\begin{array}{l}\text { NASA JSC - White } \\
\text { Sands }\end{array}$ \\
\hline
\end{tabular}

Discussion forums

Fire detection and ignition

Fire extinguishment

Human responses to combustion products and inert atmospheres

Spacecraft materials and configurations

Selection of spacecraft atmospheres 
TABLE III. - OXYGEN CONTENT AT STANDARD ALTITUDES

\begin{tabular}{|c|c|c|c|c|c|c|}
\hline \multicolumn{2}{|c|}{ Altitude } & \multicolumn{2}{|c|}{ Total pressure } & \multirow{2}{*}{\multicolumn{2}{|c|}{$\begin{array}{l}\text { Oxygen partial } \\
\text { pressure }\end{array}$}} & \multirow{3}{*}{ Comments } \\
\hline \multirow{2}{*}{$\mathbf{m}$} & \multirow{2}{*}{$\mathrm{ft}$} & \multirow{2}{*}{$\mathrm{kPa}$} & \multirow{2}{*}{ psia } & & & \\
\hline & & & & $\mathrm{kPa}$ & $\begin{array}{l}\text { Percent of } \\
\text { sea level }\end{array}$ & \\
\hline $\begin{array}{r}0 \\
1000 \\
2000 \\
2213 \\
3000 \\
4000 \\
4843 \\
5000 \\
6000 \\
7000 \\
8000 \\
8222 \\
9000\end{array}$ & $\begin{array}{r}0 \\
3280 \\
6560 \\
7260 \\
9840 \\
13120 \\
15890 \\
16400 \\
19700 \\
23000 \\
26000 \\
26980 \\
29000\end{array}$ & $\begin{array}{r}101.3 \\
89.0 \\
79.5 \\
77.4 \\
70.1 \\
61.7 \\
55.2 \\
54.0 \\
47.2 \\
41.7 \\
35.7 \\
34.5 \\
30.8\end{array}$ & $\begin{array}{l}14.7 \\
13.04 \\
11.53 \\
11.23 \\
10.17 \\
8.94 \\
8.00 \\
7.84 \\
6.85 \\
5.96 \\
5.17 \\
5.00 \\
4.47\end{array}$ & $\begin{array}{r}21.23 \\
18.83 \\
16.65 \\
16.21 \\
14.69 \\
12.92 \\
11.32 \\
9.89 \\
8.61 \\
7.47 \\
6.45\end{array}$ & $\begin{array}{r}100 \\
89 \\
78 \\
76 \\
69 \\
61 \\
-- \\
-53 \\
47 \\
41 \\
35 \\
-30\end{array}$ & b \\
\hline
\end{tabular}

Notes: a. Oxygen partial pressure calculated at geopotentlal altitudes shown based on invariant composition of 0.2094 mole (volume) percent of oxygen.52

b. Practical minimum oxygen partial pressure corresponding to earth altitude and commerical flight accilimatization.

c. Present space suit pressure, supplied with 100 percent oxygen.

d. Proposed future space suit pressure. Oxygen content could range from 29 mole percent (b limit) to 38 mole percent (sea level partial pressure). 


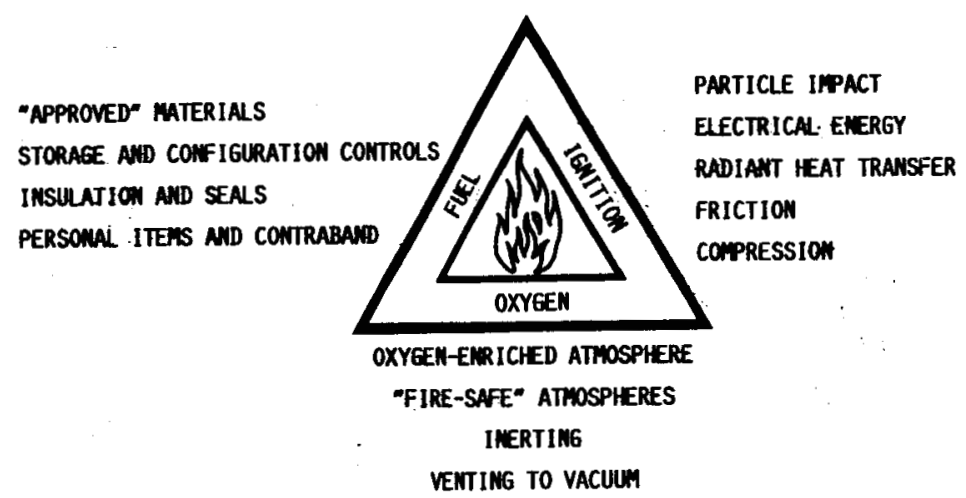

FIGURE 1. - KEY ELEMENTS OF SPACECRAFT FIRE SAFETY SHON AS THE FIRE TRIANGLE.

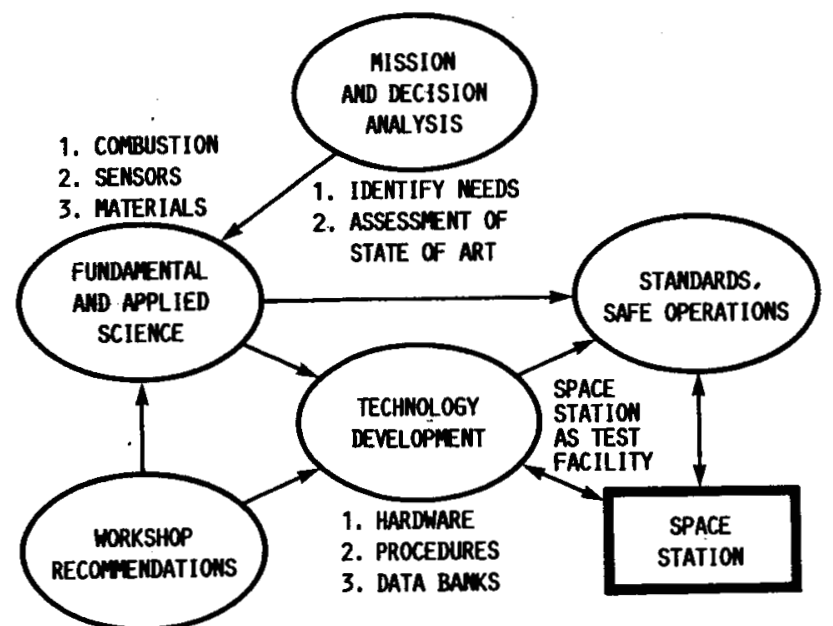

FIGURE 2. - SPACE FIRE SAFETY PROGRAM LOGIC. 


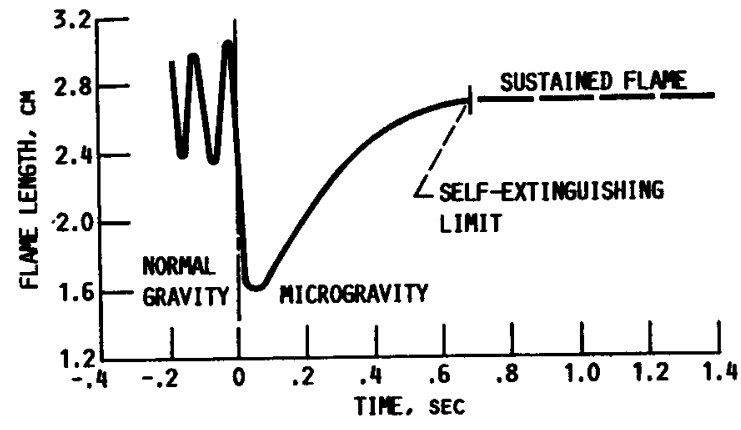

FIGURE 3. - TYPICAL HISTORIES OF LON-GRAVITY METHANEAIR DIFFUSION FLANES FOR 1.9-m-DIAEETER MOZZLE TESTS IN MASA LEMIS 2.2-SEC DROP TOMER, AFTER HAGGARD $(30,31)$.

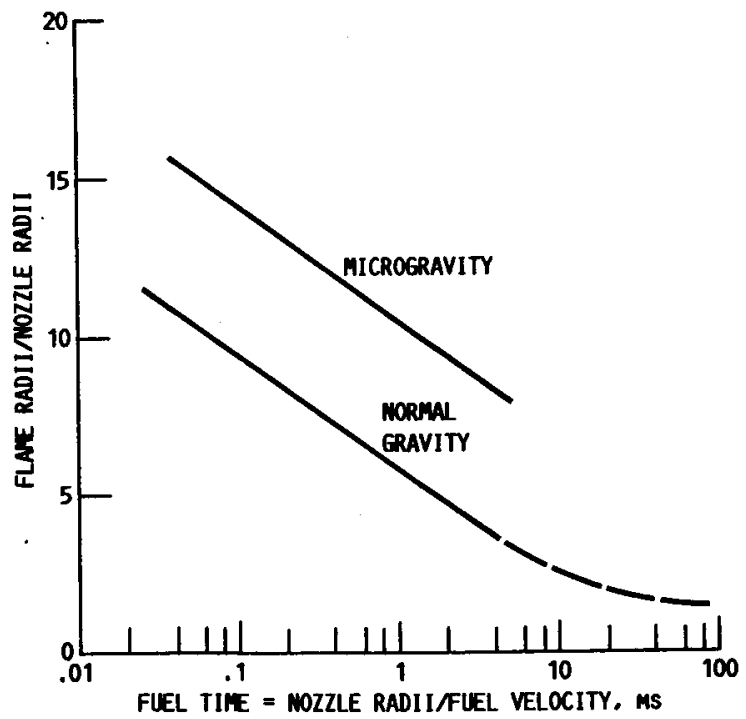

FIGURE 4. - EXPERIMENTAL CORRELATION OF HYDROCARBONAIR DIFFUSION FLANE RADII AT MORMAL AND LOW GRAVITY (31). 


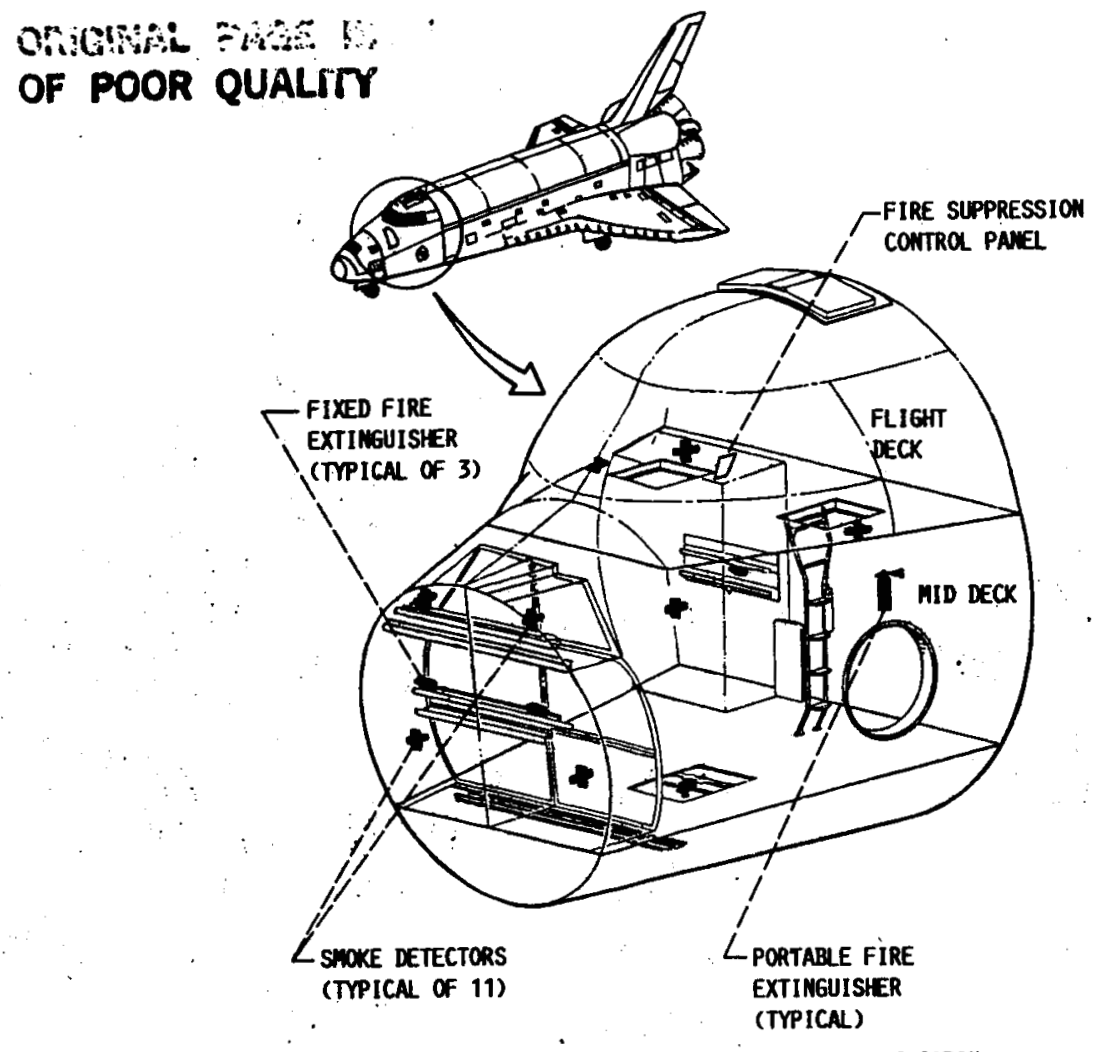

FIGURE 5. - FIRE PROTECTION IN THE SHUTTLE CABIN.

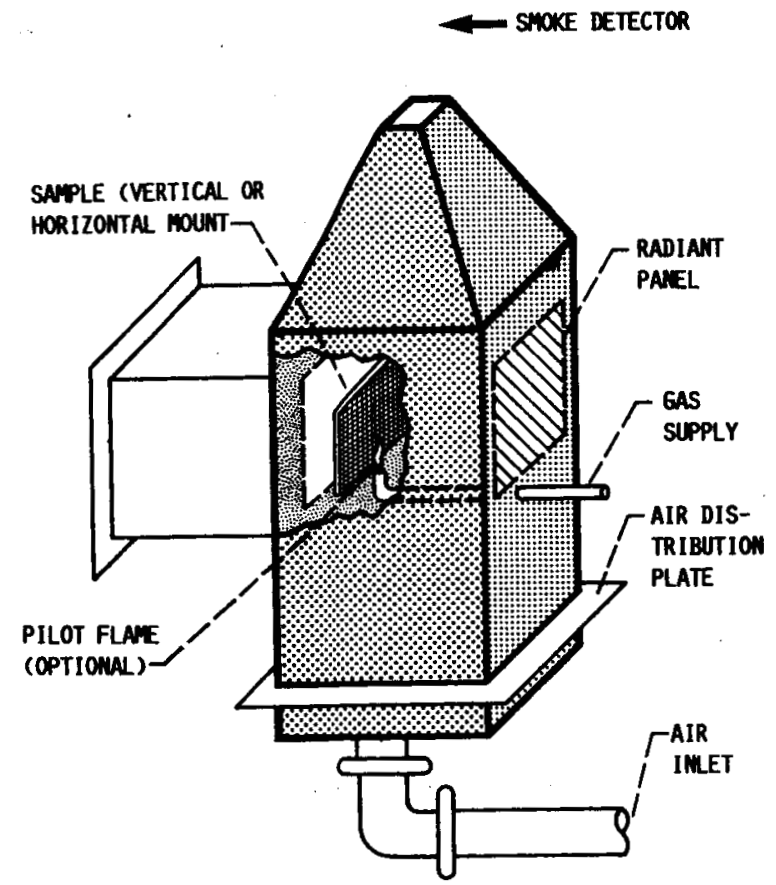

FIGURE 6. - REPRESENTATIVE HEAT RELEASE AND SHOKE TEST APPARATUS, USED FOR STANDARDIZED TEST METHOD. 


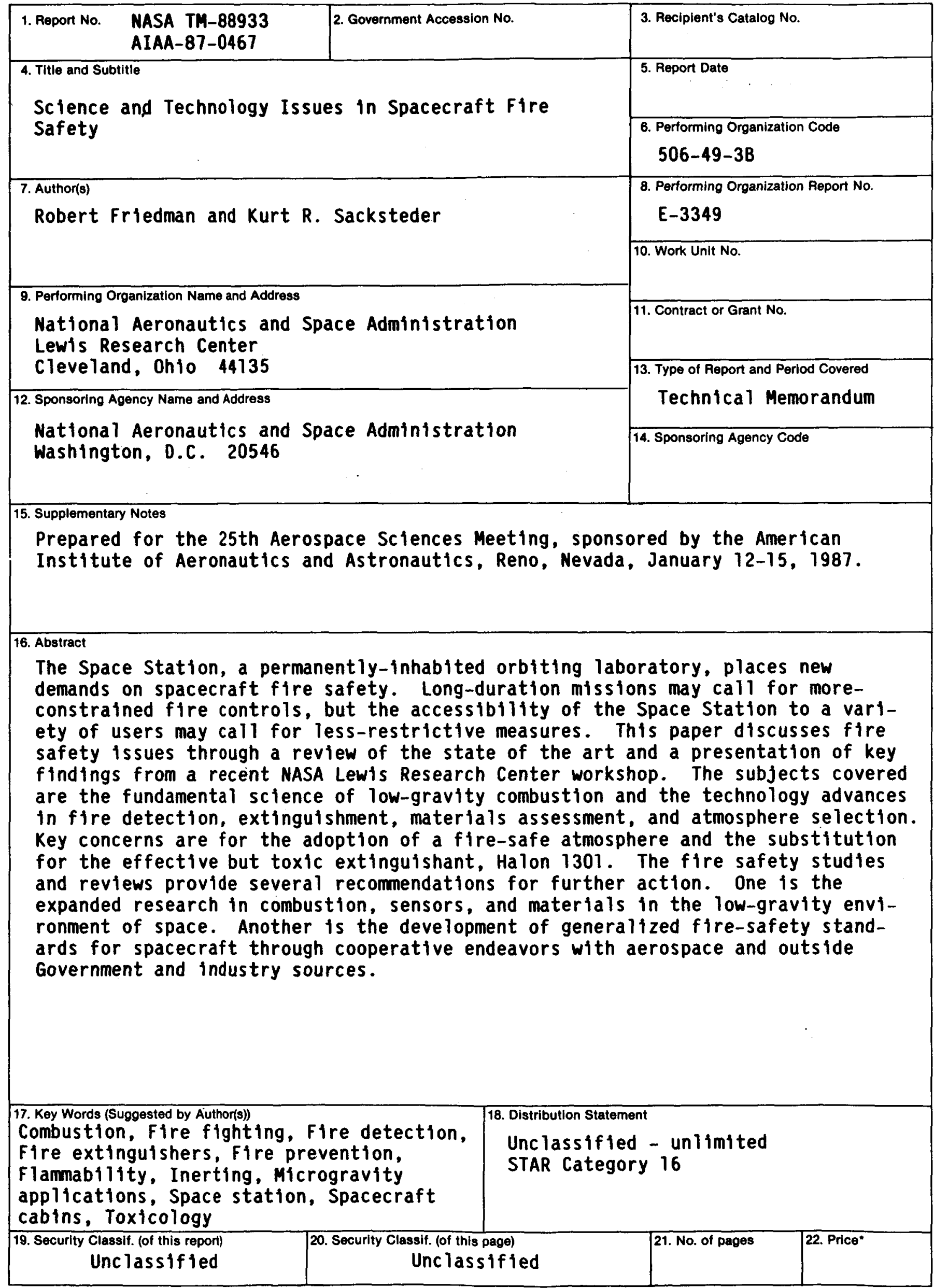

"For sale by the National Technical Information Service, Springfield, Virginia 22161 